\title{
Introduction to Research Handbook on Knowledge Transfer and International Business
}

\section{The Context}

The latter half of the 20th century witnessed a shift in the economic activity from manufacturing to services. As a consequence of this shift, we saw the emergence of a knowledge-based economy, where the reliance on knowledge to build capabilities and competencies took precedence. It thus became vital for organizations to focus on the production, communication and consumption of knowledge to sustain their competitive advantage (Grant, 1996; Grant \& Phene, 2021).

The 21 st century saw the advent and surge of the digital economy, which has persuaded many organizations to undergo rapid digital transformations. Globally, the businesses are now hyperconnected with internet, mobile technology, smart devices, the Internet of Things (IoT) and digital platforms to name a few. This also has fueled technological advancements in the areas of big data, artificial intelligence, machine learning, robotics, block chains, etc. With all of these fast-paced developments, data is now being generated from different sources, and this is often dynamic, vast and multifaceted. All of these changes further put knowledge at the core of what organizations do. Analyzing and drawing insights from this data, managing the information derived from the same and maintaining the knowledge base for the organization are all activities that firms constantly engage with. In an international business context, the effective utilization of this knowledge also requires transmission to other organizational units, which in the case of multinational enterprises (MNEs) may be often geographically dispersed units with global value chains. Further, modern day MNEs often have a wider network of global partners, as part of their coopetition strategy, which may then necessitate knowledge exchange with their partner firms worldwide. These aspects mandate a greater focus on international or cross-border knowledge transfers in MNEs, which could subsequently steer organizational learning and innovation, which are all vital for sustaining a firm's competitive advantage (Argote \& Ingram, 2000; Kogut \& Zander, 1993; Lyles \& Salk, 1996).

\section{Literature on Cross Border Knowledge Transfer}

Knowledge has been defined as a "fluid mix of framed experience, values, contextual information, and expert insight that provides a framework for evaluating and incorporating new experiences and information" (Davenport \& Prusak, 1998, p. 5). This definition also leads us to the different dimensions of knowledge, which is normally categorized as tacit versus explicit (Polyani, 1966) or procedural versus declarative (Grant, 1996). While tacit knowledge is highly contextual and linked to personal experiences that make it difficult to communicate or codify, explicit knowledge, on the other hand, is easily codified and can be articulated better. These characteristics also make tacit knowledge more valuable and highly sought after, despite the difficulties in transmitting this knowledge (Kogut \& Zander, 1992). On similar lines, 
procedural knowledge is linked to "knowing how" (mostly tacit) while declarative knowledge deals with "knowing what" (mostly explicit) (Brown \& Duguid, 1998). Knowledge creation in organizations is based on the interaction between these tacit and explicit dimensions of knowledge via the SECI (Socialization, Externalization, Combination and Internalization) model (Nonaka, 1994).

Knowledge transfer can be defined as the "process through which one unit (e.g., group, department, or division) is affected by the experience of another" (Argote \& Ingram, 2000, p. 151). The literature on knowledge transfer (KT) is mature and quite vast with diverse perspectives and, hence, is fragmented as well, which is also evident from the literature reviews and meta-analysis in this area (Michailova \& Mustaffa, 2012; van Wijk et al., 2008; Zeng et al., 2018). In fact, knowledge creation and transfer figured as one of the prominent research streams (Kostova et al., 2016), based on a review of international management articles in Journal of World Business (starting from 1960). This could be due to the fact that MNE is a superior vehicle (and considered a social community) when compared with markets for the development and transfer of knowledge (Kogut \& Zander, 1993).

KT was initially conceptualized as transmission of knowledge focusing on a sender, receiver and communication channel (Gupta \& Govindarajan, 2000), which has its origins in communication theory (Shannon \& Weaver, 1949). Gupta and Govindarajan (2000) examine the richness of communication channels, motivational dispositions of the sender and receiver and the absorptive capacity of the receiver. Following the seminal work of Gupta and Govindarajan (1991, 2000), studies exploring KT took off in a big way. Subsequent studies realized that the social context of the KT and the transformational nature of the process was largely being ignored (Becker-Ritterspach et al., 2010). So, there was a need to situate the transfer in the social context, which draws from the social learning perspective (Lave \& Wenger, 1993). Thus, some studies (Lane et al., 2001; Dhanaraj et al., 2004) started treating KT as a proxy for organizational learning (Saka-Helmhout, 2010). Further, studies on KT have also been influenced by human capital theory (Becker, 1964)and agency theory (Eisenhardt, 1989) and they mostly adopted an HR angle. Such studies (Björkman et al., 2004, 2007; Fey \& Furu, 2008; Minbaeva, 2008; Minbaeva et al., 2003; Mäkelä \& Brewster, 2009; Simonin \& Özsomer, 2009) seek to examine the effects of behavioral control mechanisms and incentive-based motivational mechanisms on KT.

The relationship between the sender and receiver units has also been examined by several KT scholars (Yamao et al., 2009; Li, 2005; Muthuswamy \& White, 2005; Khan et al., 2015). Such studies employed the social capital perspective (Nahapiet \& Ghoshal, 1998) and social exchange theory (Blau, 1964) to understand the effects of aspects such as trust, commitment, conflicts, shared vision, mutual respect and collaborations on KT. Country level effects (home versus host country) in terms of cultural distance, linguistic distance, geographical distance and institutional distance have also been found to hamper KT (Ambos \& Ambos, 2009; Jensen \& Szulanski, 2004; Evangelista \& Hau, 2009). Relative economic development and competitiveness of home versus host country also influences the dynamics of KT (Ambos et al., 2006; $\mathrm{Li}$ et al., 2007). Studies on the role of language and culture in facilitating cross-border KT have also been gathering momentum (Peltokorpi \& Yamao, 2017; Liu et al., 2015; Sarala et al., 2016; Welch \& Welch, 2008).

In terms of the antecedents of KT, organizational mechanisms or unit level (sender or recipient) characteristics have been the most widely researched. The main unit level antecedents that have been examined include absorptive capacity (Cohen \& Levinthal, 1990; Lane 
et. al., 2001; Nair et al., 2016; Peltokorpi, 2017), social and integrative mechanisms (Gupta \& Govindarajan, 2000; Hakanson \& Nobel, 2001; Björkman et al., 2004; Khan et al., 2015), communication frequency and intensity (Minbaeva et al., 2003; Bresman et al., 1999, 2009), autonomy and control (Noorderhaven \& Harzing, 2009; Foss \& Pederson, 2002) and strategic mandate and motives (Bartlett \& Ghoshal, 1986; Roth \& Morrison, 1992; Birkinshaw \& Morrison, 1995). Characteristics of knowledge were another group of antecedents that captured scholarly attention. Causal ambiguity (Szulanski, 1996; Jensen \& Szulanski, 2004; Szulanski et al., 2004), stickiness of knowledge (Szulanski, 1996), tacitness, complexity and asset specificity (Simonin, 1999a, 1999b, 2004; Dhanaraj et al., 2004) of knowledge have been found to hinder KT. Further, the attractiveness of knowledge in terms of its value, rareness, inimitability and non-substitutability (Pérez-Nordtvedt et al., 2008), as well as the relevance of knowledge (Schulz, 2001, 2003; Yang et al., 2008; Rui et al., 2016) prompt organizational units to engage with KT.

A vast majority of the extant literature focused on the KT from the parent unit to subsidiary units i.e. conventional KT (Ambos et al., 2006), going by the norm that in general subsidiaries depend on their parent units to develop their operational capabilities and enhance their knowledge base. However, as the business landscape evolved, several subsidiaries started developing superior capabilities, progressed to being centers of excellence, and became strategically important in the MNE network (Denrell et al., 2004). Such subsidiaries then became knowledge providers to the rest of the MNE network, thus triggering scholarly interest (Ambos et al., 2006; Rabbiosi, 2011; Rabbiosi \& Santangelo, 2013; Mudambi et al., 2014; Nair et al., 2018) in lateral (between subsidiary units) and reverse KT (from subsidiary to parent). Similarly, prior research has also examined several dimensions of KT, namely the extent of KT (Gupta \& Govindarajan, 2000; Harzing \& Noorderhaven, 2006a, b), degree of KT (Minbaeva, 2008), frequency of KT (Monteiro et al., 2008). These studies make the implicit assumption that all knowledge flows are beneficial. However, it needs to be noted that not all KT proves to be beneficial for the recipient. This has prompted researchers to also examine other relevant dimensions of KT, such as the benefits of KT (Ambos et al., 2006), quality and quantity of KT (Tran et al., 2010), satisfaction from KT (Li \& Hsieh, 2009) and the efficiency and effectiveness of KT (Ciabuschi et al., 2011).

\section{Aims and Objectives of the Handbook}

The primary aim of this handbook is to provide a systematic account of knowledge transfer in the international business context. To achieve this objective, we have assembled a range of interesting chapters that provide a useful insight into knowledge transfer and international business. The chapters included in this handbook offer important perspectives on knowledge transfer and international business.

\section{Structure and Content of the Handbook}

The collection of chapters is organized around the following themes.

\section{Part I - strategic perspective of knowledge transfer}

Driffield, Love and Menghinello look at technology and managerial flows between MNEs' parent units and their affiliates (located in Italy), in their chapter titled "Intra-firm trade, 
embeddedness and international knowledge transfer in the MNE". The chapter highlights the dominant parent to affiliate knowledge flows and also reverse flows as part of two-way transfers, and is based on a quantitative analysis of a unique dataset by ISTAT (the Italian National Statistical Institute). Intra-firm trade is found to be strongly related to intra-firm knowledge flows. Thus, affiliates who are well embedded into their parent's supply chain are more likely to engage in knowledge flows. While knowledge capital investments of the affiliate positively influence the reverse flow of knowledge from the affiliate to the parent, a similar effect was not seen with respect to R\&D investments. This indicates some degree of technology sourcing by these affiliates, which is then transmitted back to the parent. Export intensity was found to enhance the likelihood of affiliate-parent technology transfer while it diminished the likelihood of (one-way) parent-affiliate flows. This suggests that affiliates learn from their exporting operations and are able to develop technological capabilities, turning out to be knowledge providers for their parent units. Affiliates of Japanese MNEs were more likely (than European or American parents) to have traditional parent-affiliate technology transfer, and are very unlikely to engage in reverse transfer, indicating country specific effects. This chapter helps us understand the extent to which MNEs act as international conduits of KT.

In their chapter titled "Knowledge transfer and absorptive capacity in the context of a small multinational enterprise: A systematic study of the nexus of relationships", Øian, Kuivalainen and Vanninen examine the role of absorptive capacity in a rapidly internationalizing small MNE. This chapter is based on a single case study of a Norwegian software-as-a-service (SaaS) company founded in 2010. The study examines the four phases of absorptive capacity, namely acquisition, assimilation, transformation and exploitation and proposes antecedents that positively or negatively influence absorptive capacity. Widespread usage of ICT (informally) is found to help such small MNEs overcome resource constraints and facilitate knowledge acquisition. When it comes to assimilation, the experience of the firm is considered vital and the age of the firm and its path dependency act as mediators. Transformation is influenced by dominant logics, path dependencies, and internal harmonization of work structures within the company. Physical (stocks and other legal rights) and illusory (feeling of ownership due to a sense of purpose) ownership, which comes from having a growth-oriented culture, was found to contribute towards exploitation. Thus, this chapter delves into the development of absorptive capacity in a small MNE, which is relatively unexplored in the extant literature.

Ben Hamida examines reverse knowledge transfer in multinational companies by studying Swiss manufacturing industry. The author specifically investigates the factors that influence the extent to which knowledge transfer from foreign units to parent companies (RKT) enhances the productivity performance of the MNE at home. Based on interviews and regression analyses using detailed firm data from Swiss manufacturing, the study finds that good integration of foreign units in the whole company through close management cooperation with their parent companies contributes to enhancing the reverse knowledge transfer process, and the effect of reverse knowledge transfer is higher when MNEs' units at home have high technological capacities.

In the chapter titled "Intellectual property institutions and innovation of emerging multinational companies", Wu examines the effect of IP institutions (in host country) on the innovation in Chinese MNEs. The study examines the panel data on Chinese MNEs specifically with respect to their internationalization activities and product innovation from 2011 to 2013. It was seen that IP institutions (host country) have an inverted U-shaped relationship with Chinese 
MNEs' innovation. Further, it was also found that absorptive capacity positively moderates this relationship.

\section{Part II - Societal and human resource perspective of knowledge transfer}

Saari, Kontkanen, Arslan and Hurmelinna-Laukkanen examine the role of social capital as a KT tool in their chapter titled "Social media as a knowledge transfer tool for intellectual capital accumulation during the international growth of small firms". The authors specifically use four case studies of Finnish software firms (small firms) and examine the intellectual capital accumulation (human capital, relational capital and structural capital) of these firms during their international growth. Human capital accumulation focuses on aspects such as recruitment, training and support sources, and gathering information about new technologies and international markets using various social media platforms such as LinkedIn, Facebook, Twitter, etc. These platforms help in honing employee skills, recruiting people with the required background and experience and more importantly gather the required information about potential international markets, which in turn may help them penetrate these markets. In terms of relational capital, social media enables these firms to achieve better customer interaction and engagement, and maintain an active communication channel (also low-cost) with their partners. This in turn helps them build extensive international networks quickly, generate better international leads, sales growth and brand awareness. Social media also facilitates the maintenance and regular updating of the firm's processes, databases, and culture (which makes the structural capital). Social media thus enables firms to maintain better customer, country and market related databases; improve their marketing and sales processes; and promote a culture of learning and knowledge sharing. Thus, this chapter highlights the role of social media as an efficient KT tool (offering a low-cost option for quick, flexible KT) that facilitates international growth of SMEs.

In their chapter titled "Knowledge exchange within multi-stakeholder initiatives: Tackling the Sustainable Development Goals", Veeger and Westermann-Behaylo discuss the knowledge exchange between partners in Multi-Stakeholder Initiatives (MSIs), where MNEs, nongovernmental organizations (NGOs), and governments share information, resources, activities, and capabilities to address challenges. The cross-case analysis of four MSIs in Cape Town, South Africa, reveals that non-profit sector partners are the most actively engaged in knowledge exchange within the MSI, and the private sector is also engaged to some extent when compared with the public sector (government). The public sector is found to be least engaged, mainly because of lack of political will to engage, frequent staff reassignments, and less educated personnel. Knowledge exchanges based on joint learning, consultation, dialogue, mutuality, and trust (measures for collective stakeholder orientation) are found to be effective in MSIs. Further, the differences in absorptive capacity amongst the partners (knowledge gaps) adversely affect knowledge exchange and this can be reduced by adopting the above discussed measures of collective stakeholder orientation. Thus, an effective exchange of tacit and explicit knowledge between the MSI partners contributes to value creation and goal achievement of MSI and the private sector is increasingly embracing such collaborations to create a shared value.

In the following chapter, Tabata investigates regional talent mobility and knowledge diffusion issues in East Asia. This chapter is entitled, "Global talent mobility and knowledge diffusion: The role of staffing agencies in the growth of East Asian high-tech multinational corporations". The chapter demonstrates that labor market intermediaries such as staffing 
agencies become the trigger of talent mobility across borders, thus playing an important role in cross-national KT and regional development. The author gathered multiple-source secondary data and conducted in-depth interviews with staffing agencies of high-tech firms in Taiwan and Japan to analyze the various impacts of staffing agencies on the cross-national KT and learning, labor market institutions, and human resource development in the East Asian high-tech industry. In particular, the chapter explains that the rise and development of global staffing agencies in the East Asian region are related to the long-term recession, the restructuring of the Japanese labor market, the wage stagnation of the Taiwanese labor market and the booming economy of China. In this chapter, the author conclusively argues that East Asian capitalism has shifted from a "production-driven commodity chain", which emphasizes the internal labor market, to a "consumer-driven commodity chain", which focuses on cost reduction through the flexible arrangement of global value chain activities. From the global human resource mobility perspective, this chapter shows that staffing agencies accelerate the speed and flexibility of labor market adjustment, thereby making a crucial impact on knowledge diffusion across countries.

\section{Part III - Subsidiary knowledge creation and development}

Ho and Oh's chapter is entitled, "Technological overlap and cultural distance in MNCs' location choice of technological clusters in China". In the consideration of the fast rise of emerging economies and recently significant inward foreign direct investment to China (UNCTAD, 2021), the research setting of China (i.e., the largest foreign direct investment recipient in 2020) and multinational corporation (MNE) subsidiaries' R\&D location choice in China are topical and relevant to MNEs' international knowledge management. In their chapter, the authors used 26,981 observations of 110 Fortune Global 500 corporations from 13 countries, which includes 352 R\&D subsidiaries in 28 cities with New and High-Technology Industrial Development Zones in China between 1996 and 2007. The authors tested research hypotheses using a multi-level, mixed-effects, complementary log-log regression model. Their empirical results show that technological knowledge overlap between a focal MNE and the MNEs in a potential technological cluster has an inverted-U shape relationship with the likelihood that the focal MNE chooses to locate in the cluster, while cultural distance between the MNE's home and host countries positively moderates this relationship. Such interesting findings indicate that a focal MNE is unlikely to co-locate with other foreign MNEs that have distinct knowledge new to the focal MNE as the focal MNE will not be able to learn such knowledge from them. Nevertheless, when the knowledge of the two parties starts to become similar, the focal MNE becomes capable of relating, understanding, and valuing external knowledge. Thus, this chapter broadens existing knowledge on MNEs' KT and their geographical strategies in emerging economies.

In the next chapter, Lee, Park and Lew examine the relationship between MNE headquarters' control and their subsidiaries' capabilities. This chapter is entitled, "Building ambidextrous capabilities in foreign subsidiaries: Evidence from Korean multinationals", and investigates MNE subsidiaries' exploitative and explorative (thus ambidextrous) capabilities for knowledge development in the Korean MNE intrafirm context. In international business and management literature, it has been known that ambidextrous organizations aggressively and simultaneously pursue both exploitation and exploration of their existing and new knowledge and resources for international business activities, which leads to superior organizational performance and stability (Khan et al., 2020). However, little research has examined to what 
extent different use of control mechanisms exercised by MNE headquarters affects foreign subsidiaries' ambidextrous capabilities. As such, Lee and his colleagues develop a conceptual model based on organizational learning and ambidexterity literature and collected survey data from 398 overseas subsidiaries of 205 Korean MNEs, operating in 49 different countries. Empirical findings show that the use of outcome and social controls of MNE headquarters and double-loop organizational learning facilitate foreign subsidiaries' explorative capability. Thus, the chapter provides useful insights into subsidiary federalism and mandate as well as organizational learning and knowledge creation within an MNE.

In his chapter, Lee studies subsidiary-created knowledge utilization (SKU), conceptually drawing on organizational knowledge theory and the Socialization-Externalizatio n-Combination-Internalization (SECI) model (Nonaka, 1991; Nonaka \& Takeuchi, 1995). This chapter is entitled, "Utilization of subsidiary knowledge in multinational enterprises: Revisiting the SECI model". The SECI model has been widely used to explain how new knowledge is created and shared throughout the firm in general. Nevertheless, little research on knowledge management in MNEs examines the effective SKU process within and across the MNE boundary. In this chapter, the author proposes that the utilization of subsidiary knowledge can be framed as a process of new knowledge amplification across MNE boundaries between headquarters and subsidiaries. In doing so, the chapter offers a conceptual foundation of knowledge management between headquarters and subsidiaries by examining the holistic process of SKU and the associated knowledge transformation, thus filling gaps in the subsidiary knowledge management literature.

In their chapter titled "Absorptive capacity, value creation and new service development in multinational enterprises: The role of knowledge flows between customers, subsidiaries and headquarters", Leposky, Arslan, Gölgeci and Callaghan examine absorptive capacity as manifested in the customer-subsidiary-headquarters interface, in the context of MNEs. The authors have developed a conceptual framework with some testable propositions that focus on the subsidiary's external relationship (with customers) and internal relationships (with the headquarters). The role of absorptive capacity in service development and value creation has been highlighted, and, more specifically, the initial contribution from the customers towards this process. The chapter further delves into the different phases of absorptive capacity (acquisition, assimilation, transformation and exploitation). Knowledge acquisition is largely dependent on the relational capabilities of the firm and the specificities of the external environment. Subsidiaries' power, motivation and position in the internal network and the prevalent social integration mechanisms in the organization influence the knowledge assimilation phase. Knowledge transformation is influenced by the social integration mechanisms and alignment of support functions with the business model while the knowledge exploitation is affected by the customer's perception of value and relationship-specific capabilities. Thus, the chapter throws light on the role of absorptive capacity when it comes to a firm's success in engaging in new service development efforts across borders.

As a collection, the chapters included in this volume provide important insights related to knowledge transfer and international business. Cross-border knowledge transfer is a complex phenomenon that requires the willingness, ability and absorptive capacity of the sender of knowledge as well as the recipient of knowledge. Effective knowledge transfer also requires common language between the sending unit and the receiving unit. Effective knowledge transfer in an international context can only take place when firms utilize diverse knowledge transfer modes and mechanisms. The timing of the knowledge transfer mechanisms is vitally 
important in order to effectively transfer knowledge across borders. We hope that this volume provides potential readers with important insights on this important topic, given the important role of firms in international business activities and the need for the transfer and integration of knowledge across firms' boundaries. The contributions included in this volume aim to address some of the key themes in the literature on knowledge transfer and international business. In addition, each chapter provides important and interesting directions for future research that scholars interested in this topic could pursue in greater depth.

\section{References}

Ambos, T. C. \& Ambos, B. (2009). The impact of distance on knowledge transfer effectiveness in multinational corporations. Journal of International Management, 15, 1-14.

Ambos, T. C., Ambos, B. \& Schlegelmilch, B. B. (2006). Learning from foreign subsidiaries: An empirical investigation of headquarters' benefits from reverse knowledge transfers. International Business Review, 15, 294-312.

Argote, L. \& Ingram, P. (2000). Knowledge transfer: A basis for competitive advantage in firms. Organizational Behavior and Human Decision Processes, 82(1), 150-169.

Bartlett, C. A. \& Ghoshal, S. (1986). Tap your subsidiaries for global reach. Harvard Business Review, 4(6), 87-94.

Becker-Ritterspach, F., Saka-Helmhout, H., \& Hotho, J. J. (2010). Learning in multinational enterprises as the socially embedded translation of practices. Critical Perspectives on International Business, 6(1), 8-37.

Birkinshaw, J. \& Morrison, A. (1995). Configurations of strategy and structure in subsidiaries of multinational corporations. Journal of International Business Studies, 26, 729-754.

Björkman, I., Barner-Rasmussen, W. \& Li, L. (2004). Managing knowledge transfer in MNCs: The impact of headquarters control mechanisms. Journal of International Business Studies, 35(5), 443-455.

Björkman, I., Fey, C. F., \& Park, H. J. (2007). Institutional theory and MNC subsidiary HRM practices: Evidence from a three-country study. Journal of International Business Studies, 38(3), 430-446.

Blau, P. M. (1964). Exchange and power in social life. New York: Wiley.

Bresman, H., Birkinshaw, J., \& Nobel, R. (1999). Knowledge transfer in international acquisitions. Journal of International Business Studies, 30, 3, 439-462.

Bresman, H., Birkinshaw, J., \& Nobel, R. (2010). Knowledge transfer in international acquisitions. Journal of International Business Studies, 41, 5-20.

Brown, J. S. \& Duguid, P. (1998). Organizing knowledge. California Management Review, 40(1), 90-111.

Ciabuschi, F., Dellestrand, H., \& Kappen, P. (2011). Exploring the effects of vertical and lateral mechanisms in international knowledge transfer projects. Management International Review, 51(2), 129-155.

Cohen, W. \& Levinthal, D. (1990). Absorptive capacity: A new perspective on learning and innovation. Administrative Science Quarterly, 35, 128-152.

Davenport, T. \& Prusak L. (1998). Working knowledge: How organizations manage what they know. Cambridge, MA: Harvard Business School.

Denrell, J., Arvidsson, N., \& Zander, U. (2004). Managing knowledge in the dark: An empirical study of the reliability of capability evaluations. Management Science, 50(11), 1491-1503.

Dhanaraj, C., Lyles, M. A., Steensma, H. K., \& Tihanyi, L. (2004). Managing tacit and explicit knowledge transfer in IJVs: The role of relational embeddedness and the impact on performance. Journal of International Business Studies, 35, 428-442.

Eisenhardt, K. (1989). Agency theory: An assessment and review. Academy of Management Review, 14(1), 57-74.

Evangelista, F. \& Hau, L. N. (2009). Organizational context and knowledge acquisition in IJVs: An empirical study. Journal of World Business, 44, 63-73. 
Fey, C. F. \& Furu, P. (2008). Top management incentive compensation and knowledge sharing in multinational corporations. Strategic Management Journal, 29(12), 1301-1323.

Foss, N. J. \& Pederson, T. (2004). Organizing knowledge processes in the multinational corporation: An introduction. Journal of International Business Studies, 35(5), 340-349.

Grant, R. M. (1996). Toward a knowledge-based theory of the firm. Strategic Management Journal, 17, $109-122$.

Grant, R. \& Phene, A. (2021). The knowledge based view and global strategy: Past impact and future potential. Global Strategy Journal, in press.

Gupta, A. K. \& Govindarajan, V. (1991). Knowledge flows and the structure of control within multinational corporations. Academy of Management Review, (16), 768-792.

Gupta, A. K. \& Govindarajan, V. (2000). Knowledge flows within multinational corporations. Strategic Management Journal, 21, 473-496.

Hakanson, L. \& Nobel, R. (2000). Technology characteristics and reverse technology transfer. Management International Review, 40(1), 29-48.

Harzing, A.-W. \& Noorderhaven, N. (2006a). Geographical distance and the role and management of subsidiaries: The case of subsidiaries down-under. Asia Pacific Journal of Management, 23(2), $167-185$.

Harzing, A.-W. \& Noorderhaven, N. (2006b). Knowledge flows in MNCs: An empirical test and extension of Gupta and Govindarajan's typology of subsidiary roles. International Business Review, 15, 195-214.

Jensen, R. \& Szulanski, G. (2004). Stickiness and the adaptation of organizational practices in cross-border knowledge transfers. Journal of International Business Studies, 35(6), 508-523.

Khan, Z., Lew, Y. K., \& Sinkovics, R. R. (2015). International joint ventures as boundary spanners: Technological knowledge transfer in an emerging economy. Global Strategy Journal, 5(1), 48-68.

Khan, Z., Shenkar, O., \& Lew, Y. K. (2015). Knowledge transfer from international joint ventures to local suppliers in a developing economy. Journal of International Business Studies, 46(6), 656-675.

Khan, Z., Amankwah-Amoah, J., Lew, Y. K., Puthusserry, P., \& Czinkota, M. (2020). Strategic ambidexterity and its performance implications for emerging economies multinationals. International Business Review, 101762.

Kogut, B. \& Zander, U. (1992). Knowledge of the firm, combinative capabilities, and the replication of technology. Organization Science, 3, 383-397.

Kogut, B. \& Zander, U. (1993). Knowledge of the firm and the evolutionary theory of the Multinational Corporation. Journal of International Business Studies, 24(4), 625-645.

Kostova, T., Marano, V., \& Tallman, S. (2016). Headquarters-subsidiary relationships in MNCs: Fifty years of evolving research. Journal of World Business, 51(1), 176-184.

Lane, P. J., Salk, J. E., \& Lyles, M. A. (2001). Absorptive capacity, learning, and performance in international joint ventures. Strategic Management Journal, 22, 1139-1161.

Lave, J. \& Wenger, E. (1993). Situated learning: Legitimate peripheral participation. New York: Cambridge University Press.

Li, C.-Y. \& Hsieh, C.-T. (2009). The impact of knowledge stickiness on knowledge transfer implementation, internalization, and satisfaction for multinational corporations. International Journal of Information Management, 29(6), 425-435.

Li, L. (2005). The effects of trust and shared vision on inward knowledge transfer in subsidiaries' intraand inter-organizational relationships. International Business Review, 14(1), 77-95.

Li, L., Barner-Rasmussen, W., \& Björkman, I. (2007). What difference does the location make?: A social capital perspective on transfer of knowledge from multinational corporation subsidiaries located in China and Finland. Asia Pacific Business Review, 13(2), 233-249.

Liu, X., Gao, L., Lu, J., \& Wei, Y. (2015). The role of highly skilled migrants in the process of inter-firm knowledge transfer across borders. Journal of World Business, 50(1), 56-68.

Lyles, M. A. \& Salk, J. E. (1996). Knowledge acquisition from foreign parents in international joint ventures: An empirical examination in the Hungarian context. Journal of International Business Studies, 27(5), 877-903.

Mäkelä, K. \& Brewster, C. (2009). Interunit interaction contexts, interpersonal social capital, and the differing levels of knowledge sharing. Human Resource Management, 48(4), 591-613. 
Michailova, S. \& Mustaffa, Z. (2012). Subsidiary knowledge flows in multinational corporations: Research accomplishments, gaps, and opportunities. Journal of World Business, 47(3), 383-396.

Minbaeva, D. B. (2008). HRM practices affecting extrinsic and intrinsic motivation of knowledge receivers and their effect on intra-MNC knowledge transfer. International Business Review, 17, 703-713.

Minbaeva, D. B., Pedersen, T., Björkman, I., Fey, C. F., \& Park, H. J. (2003). MNC knowledge transfer, subsidiary absorptive capacity, and HRM. Journal of International Business Studies, 34(6), 586-599.

Mudambi, R., Piscitello, L., \& Rabbiosi, L. (2014). Reverse knowledge transfer in MNEs: Subsidiary innovativeness and entry modes. Long Range Planning, 47, 49-63.

Muthusamy, S. K. \& White, M. A. (2005). Learning and knowledge transfer in strategic alliances: A social exchange view. Organization Studies, 26(3), 415-441.

Nahapiet, J. \& Ghoshal, S. (1998). Social capital, intellectual capital, and the organizational advantage. Academy of Management Review, 23(2), 242-266.

Nair, S. R., Demirbag, M., \& Mellahi, K. (2016). Reverse knowledge transfer in emerging market multinationals: The Indian context. International Business Review, 25(1), 152-164.

Nair, S. R., Demirbag, M., Mellahi, K., \& Pillai, K. G. (2018). Do parent units benefit from reverse knowledge transfer? British Journal of Management, 29(3), 428-444.

Nonaka, I. (1991). The knowledge-creating company. Harvard Business Review, November-December, 96-104.

Nonaka, I. (1994). A dynamic theory of organizational knowledge creation. Organization Science, 5(1), $14-37$.

Nonaka, I. \& Takeuchi, H. (1995). The knowledge-creating company: How Japanese companies create the dynamics of innovation. Oxford: Oxford University Press.

Noorderhaven, N. G. \& Harzing, A. W. K. (2009). Factors influencing knowledge flows within MNCs. Journal of International Business Studies, 40, 509-526.

Peltokorpi, V. (2017). Absorptive capacity in foreign subsidiaries: The effects of language-sensitive recruitment, language training, and interunit knowledge transfer. International Business Review, 26(1), 119-129.

Peltokorpi, V. \& Yamao, S. (2017). Corporate language proficiency in reverse knowledge transfer: A moderated mediation model of shared vision and communication frequency. Journal of World Business, 52(3), 404-416.

Pérez-Nordtvedt, L., Kedia, B. L., Datta, D. K., \& Rasheed, A. A. (2008). Effectiveness and efficiency of cross-border knowledge transfer: An empirical examination. Journal of Management Studies, 45(4), 714-744.

Polyani, M. (1966). The tacit dimension. London: Routledge.

Rabbiosi, L. (2011). Subsidiary roles and reverse knowledge transfer: An investigation of the effects of coordination mechanisms. Journal of International Management, 17, 97-113.

Rabbiosi, L. \& Santangelo, G. D. (2013). Parent company benefits from reverse knowledge transfer: The role of the liability of newness in MNEs. Journal of World Business, 48, 60-170.

Roth, K. \& Morrison, A. J. (1992). Implementing global strategy: Characteristics of global subsidiary mandates. Journal of International Business Studies, 23(4), 715-735.

Rui, H., Zhang, M., \& Shipman, A. (2016). Relevant knowledge and recipient ownership: Chinese MNCs' knowledge transfer in Africa. Journal of World Business, 51(5), 713-728.

Saka-Helmhout, A. (2010). Organizational learning as a situated routine-based activity in international settings. Journal of World Business, 45(1), 41-48.

Sarala, R. M., Junni, P., Cooper, C. L., \& Tarba, S. (2016). A sociocultural perspective on knowledge transfer in mergers and acquisitions. Journal of Management, 42(5), 1230-1249.

Schulz. M. (2001). The uncertain relevance of newness: Organizational learning and knowledge flows. Academy of Management Journal, 44(4), 661-681.

Schulz, M. (2003). Pathways of relevance: Exploring inflows of knowledge into subunits of multinational corporations. Organization Science, 14(4), 440-459.

Shannon, C. E. \& Weaver, W. (1949). The mathematical theory of communication. Urbana: University of Illinois Press.

Simonin, B. L. (1999a). Ambiguity and the process of knowledge transfer in strategic alliances. Strategic Management Journal, 20(7), 595-623. 
Simonin, B. L. (1999b). Transfer of marketing know-how in international strategic alliances: An empirical investigation of the role and antecedents of knowledge ambiguity. Journal of International Business Studies, 30(3), 463-490.

Simonin, B. L. (2004). An empirical investigation of the process of knowledge transfer in international strategic alliances. Journal of International Business Studies, 35, 407-427.

Simonin, B. L. \& Özsomer, A. S. (2009). Knowledge processes and learning outcomes in MNCs: An empirical investigation of the role of HRM practices in foreign subsidiaries. Human Resource Management, 48(4), 505-530.

Szulanski, G. (1996). Exploring internal stickiness: Impediments to the transfer of best practice within the firm. Strategic Management Journal, 17(special issue), 27-43.

Szulanski, G., Cappetta, R., \& Jensen, R. J. (2004). When and how trustworthiness matters: Knowledge transfer and the moderating effect of causal ambiguity. Organization Science, 15(5), 600-613.

UNCTAD. (2021). Global Investment Trend Monitor, 38(January), 1-11.

Van Wijk, R., Jansen, J. J. P., \& Lyles, M. A. (2008). Inter- and intra- organizational knowledge transfer: A meta-analytic review and assessment of its antecedents and consequences. Journal of Management Studies, 45(4), 830-853.

Welch, D. E., \& Welch, L. S. (2018). Developing multilingual capacity: A challenge for the multinational enterprise. Journal of Management, 44(3), 854-869.

Yamao, S., de Cieri, H., \& Hutchings, K. (2009). Transferring subsidiary knowledge to global headquarters: Subsidiary senior executives' perceptions of the role of HR configurations in the development of knowledge stocks. Human Resource Management, 48(4), 531-554.

Yang, Q., Mudambi, R. \& Meyer, K. E. (2008). Conventional and reverse knowledge flows in multinational corporations. Journal of Management, 34(5), 882-902.

Zeng, R., Grøgaard, B., \& Steel, P. (2018). Complements or substitutes? A meta-analysis of the role of integration mechanisms for knowledge transfer in the MNE network. Journal of World Business, 53(4), 415-432. 
Zaheer Khan, Smitha R. Nair, and Yong K. Lew - 9781788976114 Downloaded from PubFactory at 04/26/2023 01:30:50PM 